\title{
Angles
}

New Perspectives on the Anglophone World

$8 \mid 2019$

Neoliberalism in the Anglophone World

\section{Neoliberal Metaphors in Presidential Discourse from Ronald Reagan to Donald Trump}

Jérôme Viala-Gaudefroy

\section{OpenEdition}

1 Journals

\section{Electronic version}

URL: https://journals.openedition.org/angles/625

DOI: $10.4000 /$ angles.625

ISSN: 2274-2042

\section{Publisher}

Société des Anglicistes de l'Enseignement Supérieur

\section{Electronic reference}

Jérôme Viala-Gaudefroy, "Neoliberal Metaphors in Presidential Discourse from Ronald Reagan to Donald Trump", Angles [Online], 8 | 2019, Online since 01 April 2019, connection on 07 June 2022. URL: http://journals.openedition.org/angles/625 ; DOI: https://doi.org/10.4000/angles.625

This text was automatically generated on 7 June 2022.

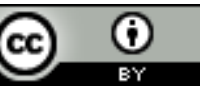

Angles est mise à disposition selon les termes de la Licence Creative Commons Attribution 4.0 International. 


\title{
Neoliberal Metaphors in Presidential Discourse from Ronald Reagan to Donald Trump
}

\author{
Jérôme Viala-Gaudefroy
}

1 Neoliberalism is an ambiguous and complex concept. Unlike Keynesianism, it is not a unified doctrine (Davies 2017: 19). It is sometimes employed without any clear definition, or its meaning reduced to laissez-faire economics. The difficulty in defining neoliberalism may come partly from the asymmetry of its usage. Today, it is used almost exclusively in the negative sense, and no one self-identifies as a "neoliberal" (Boas and Gan-Morse 2009: 138-40). Its meaning is also context-dependent and the result of a complicated historical development (Coles 2017: 21).

2 The word itself goes back to the 1890s (Oxford English Dictionary), but the idea of a new form of economic liberalism really emerged in the 1930s. It was developed by continental European intellectuals who worried about the decline of classical liberalism and the rise of government economic intervention through social programs, regulation and planning. It was rather moderate in comparison to classical liberalism (Boas and Gan-Morse 2009: 145). For the 30 years following World War II, however, a Keynesianstyle monetary and fiscal policy of state intervention in the economy became the dominant economic model. At the same time, economists such as Milton Friedman and Friedrich Hayek, who promoted market competition and criticized government intervention in the economy, became prominent thinkers in the Chicago School of Economics. As they were relegated outside the mainstream, their views grew more radical (Palley 2005: 21). The economic crisis and social turmoil of the 1970s put these "neoliberals" in the spotlight, as the economic paradigm shifted towards a favorable view of deregulation, limited governments, and free markets (Coles 2017: 21, Steger and Roy 2010: 11).

3 This major change was made visible in the economic rhetoric and policies of Margaret Thatcher in the UK, and Ronald Reagan in the US. While Tories and Republicans were fully embracing this shift, a less visible transformation was also taking place on the 
Left. In the United States, as the adjective "liberal" became a derogatory epithet among American conservatives in the 1980 s, a few left-wing intellectuals and politicians began to adopt the label "neoliberal" to describe their beliefs. Although these intellectuals never explicitly identified with pro-market policies, they greatly contributed to the acceptance of free-market principles by rejecting the legacy of the New Deal and the New Left, by criticizing programs like Social Security and Medicare, by strongly attacking unions, and by claiming to "no longer automatically favor big government or oppose the military and big business" (Peters 1983: 9). Eventually, the collapse of Soviet communism in 1989-1991 was seen by many as the triumph of a market-oriented economic philosophy now linked, at least rhetorically, to the idea of democracy and freedom (Steger and Roy 2010: 47). George H. Bush's "Freedom's victory" was presented as the victory of free markets and the defeat of political oppression in the form of planned, state-owned economies. On the left, neoliberal economics became the foundation of the "New Democrats" and the "Third Way", exemplified by the policies of Bill Clinton. The 1994 North Free Trade Agreement (NAFTA) is a good illustration of such a policy supported by every administration from Ronald Reagan to Barack Obama. It reflected a similar economic philosophy of expanding free market economies and free trade throughout the world. Despite some practical adjustments, most recently in the aftermath of the 2008 financial collapse, this consensual view lasted until Donald Trump. Domestically, however, strong disagreement remained between Republicans and Democrats on the role of government in the economy, particularly regarding the question of regulation and health care.

4 Still, some scholars have shown that neoliberalism does not necessarily mean limited governments. Neoliberalism, they claim, is not about states ceding power but about "replacing political judgment with economic evaluation" and "justifying decisions in terms of logic of markets" (Davies 2017: 21). This means that neoliberalism is not the same as classical liberalism - with its emphasis on free markets - but rather takes the form of state planning for free markets and competition. However, the case remains that from a rhetorical viewpoint, both in terms of what the neoliberals say, and what critics often say they are obsessed with, neoliberalism has consistently pushed free trade and free markets.

This paper focuses precisely on the rhetoric regarding these two tenets of neoliberalism. It explores how US presidents have produced and shared a coherent narrative since the early 1980s, including on the role of government in the economy, despite political differences on a topic like health care. This discourse is characterized by the sacralization of free markets and free trade, on the one hand, and a wary view of government intervention as an impediment to freedom, on the other. This article also argues that, although Donald Trump's rhetoric may appear to mimic that of his predecessors, his discourse actually represents a disruption in the doxa regarding trade or the expansion of the free market. Drawing on the rhetorical and cognitive approaches established by Lakoff and Johnson (1981), and further developed by Chilton (2004), and Charteris-Black (2011), this article analyses the conceptual metaphors that both reveal and produce concrete meaning for abstract economic notions. As linguist George Lakoff and philosopher Mark Johnson have shown, metaphors are meaningful windows onto the historical, cultural and social experience of a country, and the metaphorical structure of the fundamental concepts in a culture is coherent with the basic values of that culture (1981: 22). More than a figure of speech, a metaphor is, first and foremost, a tool for understanding and framing. It operates as a device of 
simplification by using familiar meaningful terms to talk about unfamiliar and often abstract concepts. Market and trade are, for instance, commonly framed through metaphors of physical freedom like movement and journey. This means that "free market" and "free trade" are understood not as mere economic systems but rather as basic rights virtually indistinguishable from democracy and political freedom, making regulations and government intervention impediments to freedom. President Clinton's concept of "market democracies" in the 1990s epitomized this fusion between political and economic freedom.

\section{A Deterministic Model}

6 According to Lakoff, freedom itself is an abstract political concept with a tangible reality often "expressed through metaphors fundamentally understood in terms of our bodily experiences," particularly through the metaphors of movement and journey (2006, 29-30). Such metaphors enable politicians and presidents to conceptualize longterm purposes, including economic and political goals in foreign affairs.

\section{Metaphors of Journey and Movement}

7 In the United States, many considered the end of the Cold War as Ronald Reagan's victory, a vindication of his policy and free-market rhetoric. After all, Ronald Reagan had warned the world that the free market was "the one true path" to development (1987-09-21). The exultation of the "end of history" even led some to believe that the advent of liberal democracy and the capitalist market represented the final stage of human evolution. As the Soviet bloc was collapsing, President George H. Bush expressed his delight that former communist countries were "taking early steps towards free markets" and "that the world move[d] in this direction" (1990-01-12). Similarly, Bill Clinton presented the free market and democracy as "the only proven path" to follow (1994-07-07), and as the traveler "on the march" (1995-05-08), and Barack Obama noted that "countries like China, India, and Brazil [were...] moving toward market-based principles" (2011-05-25). This discourse of a progressive movement represents more than a simple motion forward; it signals a journey because it has direction and purpose. Life-as-a-journey is a common metaphor in the English language (Charteris-Black 2004: 74). There is evidence to suggest, however, that journey metaphors are more prevalent in American political discourse (Charters-Black 2004: 107), perhaps because it resonates with the American historical experience of journeys westward, across the land or across the sea. Ronald Reagan, for instance, presented free trade and free markets in navigational terms, and advocated to get "the boat of free markets and free trade [...] moving in the direction of prosperity," comparing trade war to "shooting holes" and calling for strengthening "the boat of free markets and fair trade so it can lead the world to economic recovery and greater political stability (1982-20-11). In her study of President Reagan's trade rhetoric, political scientist Delia Conti concludes that this was his "most frequently-used trade metaphor" (1995:101). It is a powerful imagery of experiential collectivity: "We're in the same boat with our trading partners", he also said in the same speech, thus emphasizing the stakes and the risks of trade wars that could sink the boat. The journey may also be vertical. For instance, President Reagan also compared freedom in the marketplace to a "ladder of social and economic advancement for all people, step 
by step improving the lot of every individual from top to bottom." (1985-06-21). This upward movement emphasizes success from a hierarchical business-like perspective (Eubanks 2000: 156).

In times of crisis, journey metaphors become useful rhetorical tools, as they offer guidance and provide confidence. In 2008, presidents Bush and Obama both reiterated that free people and free markets were the "surest path" to prosperity and growth (2008-11-14, 2008-11-15, 2011-03-19). These metaphors also encourage the audience to accept "short-term suffering for worthwhile long-term objectives" and they help make sense of a dire situation by giving it a moral perspective (Charteris-Black 2011: 67). This is how Barack Obama used this metaphor at the beginning of his presidency when the financial meltdown was becoming a full-blown crisis:

Our journey has never been one of shortcuts [...] the long, rugged path toward prosperity and freedom. (Inaugural Address, January 20, 2009)

It is time to put in place tough, new, common sense rules of the road so that our financial market rewards drive and innovation, and punishes shortcuts and abuse.

(Address Before a Joint Session of the Congress, February 24, 2009)

Here, "shortcuts" amount to cheating and to an easy way out of the rules, contrary to "the long, rugged path" of the national journey, a reminder of the pioneer's journey that emphasizes the protestant work ethic that ultimately leads to "prosperity and freedom" (2009-20-02). The journey metaphor doubles as a justice metaphor (shortcuts are wrong / long journeys are right). Here, the value of the reward is thus correlated with the hardship of the journey. In all these instances, capitalism is destined to succeed and expand, and Americans are on a mission to redeem and remake the world in their own image, a variation of the old American concept of Manifest destiny.

\section{Metaphors of Nature: Garden, Water and Weather}

10 Presidents also use organic metaphors and metaphors of nature to frame the "natural" outcome of the journey as peace and prosperity. Ronald Reagan praised "international trade" for providing the "fruit of human talents that transcend boundaries of geography and culture" (1988-05-05). George H. Bush associated markets with "fruits" (1990-12-03) and a "harvest that everyone can share" (1989-09-25), and Bill Clinton stated that free markets were "growing" and "flower[ing] throughout the world" (07-26-1993), and that you could "reap their benefits" (1997-09-22). He also declared with satisfaction that they were even "taking root on every continent" (1996-08-05). Such metaphors are evocative of the Garden of Eden, an image used extensively by President Clinton who dreamed of "a garden of democracy and prosperity and free enterprise in every part of this globe" (1993-02-26).

11 The idea that the land will magically produce growth and wealth brings to mind the myth of the frontier, and what historian Richard Slotkin called "bonanza economics" linking economic growth to the discovery of new land (1993: 17-8). The vast, untapped reserves of free land in the old West became the new overseas markets that need "opening up" (1988-05-05, 1993-02-17, 1998-01-7, 2008-01-28). With the success of the space shuttle, Ronald Reagan even saw space, the ultimate new Frontier, as a place offering "new opportunities for free enterprise" (1985-02-06). Along with the journey metaphor, these tropes form a metaphorical network deeply rooted in the American mythical past. Here too, metaphors serve as political tools to illustrate a complex situation in simple terms that echo the national mythology, and resonate with the way 
Americans understand their mythical position in the world. Organic metaphors also reinforce the idea that expanding free market capitalism is determined by nature itself.

Free trade is also commonly presented through organic metaphors, in particular liquid metaphors:

The freer the flow of world trade, the stronger the tides for economic progress and peace among nations. (Radio Address to the Nation on International Trade, August $6,1983)$

In presidential discourse, free trade has been frequently associated with the "free flow" of a variety of elements that include goods and ideas (1991-09-23), goods and services (1993-02-26), goods and capital (1995-04-20), information and people (1998-05-18), and more generally and most commonly, of commerce (1990-03-08, 1994-09-28 2002-05-14, 2006-07-31, 2006-10-13, 2011-28). Other organic metaphors may also result in making economic crises seem more "natural" and therefore more acceptable. In his remarks on the national economy in 2009, for instance, Barack Obama employed a weather metaphor to talk about the recession:

This recession [...] was caused by a perfect storm of irresponsibility and poor decision-making [...]. Markets and economies naturally ebb and flow [...] a normal downturn in the business cycle. (Remarks on the National Economy, April 14, 2009)

14 The image of the storm underlines the exceptional and violent quality of the crisis as opposed to the regular "ebb and flow" of markets and economics - an expression that evokes the "natural" tide of the business cycle, an image also used by Ronald Reagan (1983-08-06). The connotation is that crises are part of the laws of nature, and the solution is not to change the system but to better prepare through new policies. This association of nature and a capitalistic economic system connotes a deterministic model.

15 The water metaphor is also one of Donald Trump's favorite tropes but, contrary to his predecessors, he sees this flow as something dangerous, invasive and dangerous from which protection is needed. The reduction of trade barriers, he says, has "allowed foreign goods to flow freely into our country" (2017-10-11). He applies the metaphor to more than just commerce, using it to evoke more pressing threats from the outside world. One of the greatest threats to the American nation, according to Trump, is the flow of illegal immigrants who have "flooded in" (2017-29-04). Dangerous elements, people associated with crime, violence (particularly the MS-13 gang), drugs and terrorism (2017-24-02, 2017-26-02) are "pouring" across the border. Whether it is people or commerce, these metaphors illustrate Donald Trump's unerring vision: the world is a dangerous place with potential threats from which the nation must be protected through physical walls or economic tariffs.

\section{Machine Metaphors}

Paradoxically, the market may also be presented as an artificial construction through the machine metaphor. ${ }^{1}$ Just like organic metaphors, the machine metaphor illustrates the inescapability of the free market economic system as well its progressive nature. In his 1988 State of the Union Address, four months after the October 19 "Black Friday" stock market crash, President Reagan continued to express his belief in "the free market as an engine of economic progress" (1988-01-25). George H. Bush used the same imagery of the "engine of progress" (1990-01-31) that would "fuel growth" 
(1989-09-25) and George W. Bush talked about trade and free markets as "the engines of the world's economy" (2005-02-21). Similarly, President Clinton called them "the best engines we know of for raising living standards, reducing global poverty and environmental destruction, and assuring the free flow of ideas" (2000-01-27-) or the "great engines in this extraordinary economic machine" (1994-10-24). The machine metaphor sometimes overlaps with a movement metaphor driven by consumers who "determine the direction and the workings of the marketplace" (1994-07-07, 1994-10-24).

This machine metaphor continued to be used even after the 2008 financial meltdown: if the market machine is not "functioning," declared George W. Bush, it is because it needs "the grease necessary to keep the gears of our financial system turning," i.e. liquidity (2008-10-10). The crisis is therefore not a failure of the machine, but only a temporary malfunction that needs "fixing" (2008-11-13). Even Barack Obama, who was more circumspect and recognized market failures, employed the same metaphor to emphasize how the "market can spin out of control" (2009-01-20) and how the freemarket machine only needs "smart regulations" to "work as it should," to "work better" (2011-05-25, 2012-01-24).

These examples illustrate how, in the last 35 years, the United States presidents have all framed market and trade through the same metaphors that emphasize a sense of inevitability within the neoliberal philosophy. Remarkably, Donald Trump seems to be breaking with this doxa of the past 40 years on two accounts. Firstly, because althoughhe has been using the organic metaphor to speak about free trade, he has primarily presented it in negative terms, as a threat to the nation's interest and economic health. Secondly, contrary to his predecessors, he has shown no interest in spreading either political or economic freedom throughout the world. In fact, in the first year of his presidency, he only mentioned "free market" in two of his remarks and speeches, and only once in his tweets. The comparison with his predecessors is striking, as shown in the following graph: 
Comparison of the number of presidential speeches and remarks containing the phrase "free market" in the first year of each presidency (1945-2017).

Comparison of the number of presidential speeches and remarks containing the phrase "free market" in the first year of the presidency. 1945-2017

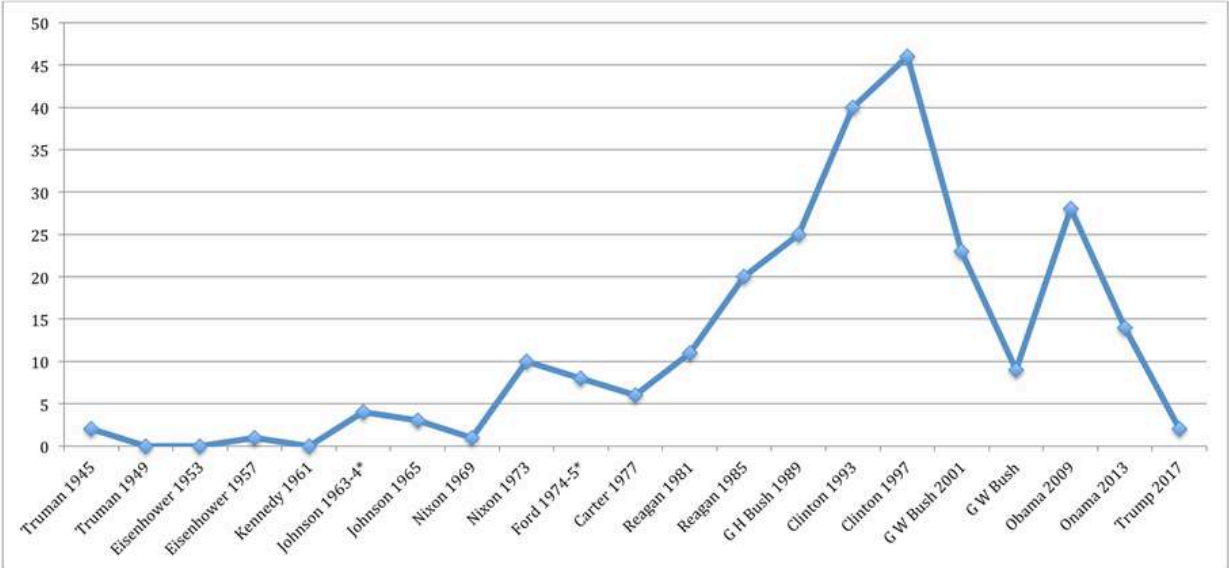

Comparative computer-generated analysis with the R program for Statistical Computing of the presidential papers archived online on The American Presidency Project, University of California
$<$ http://www. presidency.ucsb.edul>.

*in the cases of the first Johnson presidency and the Ford presidency, the speeches and remarks taken into account cover a 12 month period.

Source: comparative computer-generated analysis of the presidential papers archived on The American Presidency Project, University of California, https://www.presidency.ucsb.edu/.

The only market Donald Trump seems to be interested in is the stock market, the growth of which he attributes to his election. He mentioned it in 75 of his speeches and in 42 of his tweets within the first year of his presidency. It would be premature to conclude that Donald Trump is not a neoliberal in his own right, however.

\section{A Moral Model}

As free markets and free trade have been presented as the only economic options that lead to peace and prosperity for the United States and the world, they have also been framed in moral terms, most notably by linking economic freedom to political freedom. In his address to the United Nations General Assembly in 1986, Ronald Reagan made the organic connection very clear: "economic freedom," he said, "is the inseparable twin of political freedom and democratic government." (1986-09-22). With the end of the Cold War, political freedom and free markets were constantly associated to the "triumph of liberty over dictatorship in every corner of the globe" (1990-05-12) and to the liberation from "oppression" (1993-04-01, 2001-02-27). Bill Clinton linked human rights to the market by calling for the expansion of "market democracies" at the United Nations (1993-09-27) and George W. Bush reinterpreted the commitment of NATO and the European Union to a commitment of "democracy, free markets, and common security" (2001-06-15). Similarly, Barack Obama saw a historic trend toward "free societies, free governments, free economies, free people" (2011-11-17). The free-market economic model has also been presented through a number of metaphors that precisely emphasized its moral nature. 


\section{Personification}

21 Just as recent presidents have often spoken allegorically about freedom, they have also repeatedly given human qualities to the market. George H. Bush noted that free markets are "well-informed" and constitute a system with "wisdom" (1990-02-05), whose actions are moral as they contribute to the "defense of the environment" (1990-02-05), and even "provide levels of prosperity, growth, and happiness" (1991-09-23); Bill Clinton emphasized the "power" and "logic" of the free market (1999-06-12); and Barack Obama saw open markets as agents of change, providers of the "chance to create and succeed" (2011-09-11). In other words, they warrant the American Dream. George W. Bush also embraced the moral view of free markets and trade that "have helped defeat poverty and taught men and women the habits of liberty" (2003-05-09, 2001-07-17). In this moral account, opposing free trade or the free market is morally wrong. "Those who protest free trade are no friends of the poor," since they "deny them their best hope" (2001-07-17). George W. Bush made it clear that markets were no longer a means, but an end in themselves: if "corporate criminals must pay a price", he claimed, it is for no other reason than for "the sake of our free market" (2002-09-26).

Even as the effect of the financial crisis continued to worsen, Barack Obama urged his audience to "help restore a free market that's fair" (2009-05-17-9). The word "restore" implies a health metaphor, a common conceptual metaphor in times of economic crises which identifies the status of the market with terms like "health," "healthy," "recovery." The "flow of credit" was compared to "the lifeblood of our economy" (2009-02-24, 2009-02-10). It was one of the most recurrent metaphors used by President Obama at the beginning of his first term (Sacco 2009). On the other hand, regulations were no longer obstacles to economic freedom but necessary elements in a "healthy market" in which "a quick profit" was considered unhealthy (2009-02-24). The belief in the morality of the market, just like the belief in American exceptionalism, also stems from a positive view of competition grounded in a strong sense of self-confidence prevalent in American culture (McNaught 2009: 126).

\section{A New God?}

Not only is the market presented as a moral agent and a benevolent force, it is also endowed with supernatural power. Ronald Reagan referred to the "magic of the marketplace" in more than 15 different speeches between 1981 and 1988, including in his more prominent remarks:

[...] the United States believes the greatest contribution we can make to world prosperity is the continued advocacy of the magic of the marketplace [...] (Address to the $41^{\text {st }}$ Session of the United Nations General Assembly in New York, September 22, 1986.)

As China was opening up to a market-oriented economy, he noted how the "free market spirit" had "enlivened the Chinese economy" (1984-05-01), and in his famous speech at the Brandenburg Gate in West Berlin in 1987, President Reagan marveled at how "free markets are working miracle after miracle of economic growth" (1987-06-12). In a less dramatic fashion, George H.W. Bush called the market a power "unleashing a new force" (1989-02-09), and a "force of progress" (1989-09-25). Expressing his belief in America's mission after the fall of communism, Bill Clinton 
called on Americans to become "leaders in the great crusade of the post-Cold War era to foster liberty, democracy, human rights, and free-market economies throughout the world" (1993-03-26).

The market was not just powerful, according to Barack Obama it is the "greatest force the world has ever known for creating wealth and opportunity" and "for economic progress in human history" (2011-11-17, 2012-04-10). God's promise to the Pilgrims has become "the promise of the free market" (2011-01-28) and its power is what America's "ultimate success will always depend upon" (2010-08-09). If one defines religion as humanity's "acknowledgement of a greater or a superior power to which one owes fortune, obedience and respect," then the similarities between the market and God himself become striking (McNaught 2009: 129).

Applying his belief in America's mission to expand freedom to the world through economic opportunity, George W. Bush was explicit in expressing his vision of the powers of the free market and free trade "to transform our world" (2006-02-15). In his 2002 State of the Union address, he claimed that "in every region, free markets and free trade [...] are proving their power to lift lives" (2002-01-29) - "lift" evokes a verticality traditionally associated with spiritual transformation. According to President Bush, free markets have quasi-magical powers of social transformation that can be applied "to the needs of the poor" through free trade (2001-07-17). This power of transformation echoes America's own mythical story of a country transformed "from a rugged frontier to the greatest economic power in history" (2008-11-14).

Through these metaphors, we can identify a number of characteristics of the free market traditionally attributed to the divine. Firstly, it is benevolent, as it is a force that brings peace and prosperity. Secondly, it is omnipotent, since it is unavoidable and part of natural law. Thirdly, it is omniscient, as it meets the needs of all people. And finally, it must become omnipresent, as the goal is to expand it throughout the world so it can be felt everywhere at the same time. On the whole, these metaphors seem to confirm the view of economist Lester Thurow that market theory "is a political philosophy [...] approaching a religion" (Thurow 1984: xviii). This was true until Donald Trump's election, who, contrary to his predecessors, has virtually no interest in political freedom and democracy, except for a few opportunistic rhetorical mentions of Cuba, Venezuela, Syria and North Korea.

\section{Trade-is-a-game Metaphor}

Free trade in particular is commonly framed through game metaphors. It is an attenuated, less hostile version of the war metaphor as it involves not only winners and losers but also rules and order. It is also a very common metaphor in the culture and language of business (Hamington 2009: 473). The game metaphor is essentially a moral metaphor that brings into play concepts of fairness and justice. The core narrative of this metaphor is that Americans will necessarily be the winners, as long as the rules are fair.

One of the main arguments put forth by presidents in support of free trade agreements is that, through these deals, they are able to "level the playing field" of commerce. This sports metaphor is a subset of the game metaphor and is one of the most recurrent expressions used for international trade in politics. Every president from Ronald Reagan to Barack Obama have used this metaphor to push for free trade agreements 
that would standardize the rules and "level the playing field" for the American workers. As the following excerpts show, this game metaphor is expressed in a striking similar fashion in presidential discourse:

If the United States can trade with other nations on a level playing field, we can outproduce, outcompete, and outsell anybody, anywhere in the world. (Address Before a Joint Session of Congress on the State of the Union, February 4, 1986)

Level the playing field, and Americans will outthink, outproduce, and outperform anyone, anywhere, anytime [...] I put my faith in your talent to compete: America doesn't cut and run. We compete. (Remarks at Louisiana State University in Baton Rouge, Louisiana, March 6, 1992)

Given a fair chance and a level playing field, we can out-innovate, out-produce, and out-compete any people. (The President's Radio Address, November 20, 1993)

With open markets and a level playing field, no one can outproduce or outcompete the American worker. (Address Before a Joint Session of the Congress on the State of the Union, January 31, 2006)

Our workers are the most productive on Earth, and if the playing field is level, I promise you, America will always win. (Address Before a Joint Session of the Congress on the State of the Union, January 24, 2012)

Each quote also expresses a strong belief in national superiority, evoking American exceptionalism and self-confidence. The reasoning is always that trade agreements will "level the playing field" for American workers who will be able to completely and necessarily win. Bill Clinton tried to convince the unions that NATFA was a good agreement for the American workers using this game metaphor (1994-24-09), and it is also how Barack Obama introduced the negotiations on a Trans-Pacific Partnership (TPP) (2013-02-12). The game metaphor also implies that the freedom that comes with "free trade" and "free market" is not laissez-faire but rather based on fair rules.

Ronald Reagan was the one who redefined free trade as fair trade to justify his protectionist measures, particularly regarding Japan, while remaining consistent with the principles of free trade and competitiveness (Conti 1995: 92).

We had clear evidence that Japanese companies were engaging in unfair trade practices that violated an agreement between Japan and the United States. We expect our trading partners to live up to their agreements. As I've often said: Our commitment to free trade is also a commitment to fair trade. But you know, in imposing these tariffs we were just trying to deal with a particular problem, not begin a trade war. (Radio Address to the Nation on Free and Fair Trade, April 25, 1987)

President Bush senior and President Bush junior both declared that freedom and fairness go hand-in-hand (1990-01-31, 2004-01-20). Similarly, Bill Clinton saw in freetrade agreements opportunities to shape global commerce and guarantee that the rules are fair to the American workers. In 1997, he advocated that a "yes vote" for free-trade deals "means that America helps to write the rules for the new global economy" (1997-11-08). This was the reason for participating in trade deals, including as recently as 2015 with the TPP (2015-01-20). The president ensured that the trade deals would be beneficial as long as the trading partners "played by the rules" (2015-01-25).

These metaphors reveal a coherent consensual view of the market as a benevolent force inasmuch as it works fairly, i.e. according to rules that America could write and enforce. The failure of the market is essentially that of the individuals who misuse it. It is seen as an anomaly in the game. As Presidents from Ronald Reagan to Barack Obama all share this vision, it might be considered to have become a national mythology in itself. 
Donald Trump may be seen like a heretic in this respect, however, at least rhetorically speaking. It is important to note that Donald Trump has used the same game metaphors for trade and has expressed a similar belief in American exceptionalism. "When there is a level playing field, -and I've been saying this for a long time-" he said to Boeing workers in Charleston, "American workers will always, always, always win" (2017-02-17). This is what other presidents had said for decades, which is why the idea that "the terrible trade deals" are why American workers were not given that "level playing field" should resonate with the so-called "forgotten Americans" (2017-02-21). Expanding on the game metaphor, Trump takes on the heroic role of the righter-of-wrongs in a world divided between winners and losers, promising that "America is going to start winning again, winning like never, ever before," and that "we're not going to let our country be taken advantage of anymore" (2017-02-17). In this speech, Trump offers once again a very antagonistic view of the outside world akin to a villain doing "tremendous cheating." His rhetoric also signals a semantic shift in which "fair trade" has replaced "free trade" as the main goal put forth by his administration, which he stated very clearly:

So I know that's always been a point of contention, but to me it's just fair. It's just fair. It's reciprocal. It's fair. And so we're going to be doing a lot of work on that, and that's becoming a very, very important factor-fairness. Because I believe in free trade. I want so much trade-somebody said, oh, maybe he's a total nationalist -which I am, in a true sense-but I want trade. I want great trade between countries. But the word "free" is very deceiving, because it's good for them, it's not good for us. I want fair trade. (Remarks to the National Governors Association, February 27, 2017)

If Donald Trump sounds like a disrupter, his rhetoric offers a moral narrative that is essentially coherent with the story told by previous presidents. It is undeniable that his opposition to free trade deals conflicts with one of the tenets of classic laissez-faire economic liberalism. This does not signal, however, a return to the post-war Keynesian economics.

\section{Obstacles to Economic Freedom}

One important way to understand the real impact of neoliberal thinking is to study what constitutes obstacles to prosperity and freedom in presidential discourse.

\section{The Shifting Meaning of the Wall}

37 For decades, presidential rhetoric conceived of walls and barriers as obstacles to economic and political freedom. This metaphorical framework was firmly situated in the narrative of the Cold War in which obstacles to freedom, both economic and political, were symbolized by the "Iron Curtain," barriers, and walls. When Ronald Reagan famously asked USSR Premier Gorbachev in his speech at the Brandenburg Gate in West Berlin in 1987 to "tear down this wall," he linked political freedom and peace to the "economic miracle" of free market and free trade. Similarly, his successor, George H. W. Bush, praised "freedom's advance" in "a movement towards political pluralism and a free-market economy," adding that "barriers stand in the way" and "unneeded restrictions and regulations act as dead weights on their own economies and [are] obstacles to foreign trade" (1989-25-09). Bill Clinton warned of "democracy's prospects 
[...] dimmed [...] by trade barriers" (1993-26-02) and later celebrated the dismantling of "the blocs and barriers that divided our parents' world" and the hard work of governments "to tear down trade barriers abroad" (1993-04-02). George W. Bush cited Ronald Reagan's speech in West Berlin, commended him for believing "that no human barrier could hold back the spread of human liberty" (2003-11-11). In his last State of the Union message, Bush promised he was working "to break down barriers to trade and investment wherever we can" (2008-01-23). In his discourse, regulations and tariffs constitute obstacles that "prohibit the free flow of trade" (2008-04-21). Naturally, it follows that such barriers must be "lowered" (1991-02-06), "reduced" (2012-05-19), or "eliminated" and "torn down" to allow for the circulation and flow of economic activity (1990-06-11, 1998-06-08, 1998-05-18, 2005-09-14).

Even as the most serious economic crisis since the Great Depression was looming, the priority was still to maintain the free market and the "free movement of goods and services," George W. Bush warned in the wake of the 2008 financial meltdown (2008-11-14). Barack Obama continued to be largely influenced by the Cold War narrative when, in Strasburg, France, he reminded the Europeans that "we must not erect new barriers to commerce, that trade wars have no victors," and that "the freedom that our nations stood for throughout the Cold War was the opportunity that comes from free enterprise and individual liberty," (2009-03-04), pointing also to the uselessness of "walls of concrete and barbed wire" that "are ultimately no match for the will of ordinary men and women who are determined to live free" (2014-07-11).

This is where Donald Trump's rhetoric constitutes a dramatic shift from all his predecessors since the 1980s. His narrative frames the nation as a container that is under constant threat from dangerous elements "pouring and flooding in". The main conclusion of this narrative is the need to build walls and barriers as a means of protection (2017-25-01). Trump's key surprising difference, especially compared to previous presidents, is that his rhetoric as a candidate is very similar to his rhetoric as a president. President Trump has continued to repeat his promise to build a "great wall", "a real wall, not a little wall like some people said" (2018-02-02), "a great border wall to stop dangerous drugs and criminals from pouring into our country" (2018-23-02). In addition to his promised great southern border wall, he also refers to what could be called a "protectionist wall" through the renegotiation of NAFTA (2018-01-05), which led to the rebranding of NAFTA into USMCA to give the president a political win (Donnan 2018). This protectionist wall also takes the form of tariffs imposed as a form of punishment on countries deemed unfair to the United States like China or Canada, but also against countries that refuse to take back their criminals (2018-02-02). He even connects the metaphorical and the physical walls by promising that the wall on the border will be paid for by Mexico with what it "makes from the U.S.," thanks to NAFTA (3:25 AM - 18 Jan 2018).

\section{Government vs. Freedom}

One of the most visible features of neoliberal thinking is a shift in the role of government that has occurred since the 1970s, when a rollback of the government's regulatory power began with the first wave of deregulation. It was Ronald Reagan who popularized a more anti-government rhetoric, encapsulated in his now iconic remark in his 1981 Inaugural Address: "government is not the solution to our problem; 
government is the problem." In economics, the government is seen as an obstacle to the workings of the free market machine:

Government, with its high taxes, excessive spending and overregulation, had thrown a wrench in the works of our free markets. In essence government was trying to run the economy, but was ruining it instead. (Remarks to Brokers and Staff of the New York Stock Exchange in New York, March 28, 1985)

His successor, George H. Bush, continued to promise "fewer regulations" and "less bureaucracy" (1989-02-09). Even at the end of his term, he continued to present taxes and regulations in terms of "obstacles" that "hinder growth" and must be "cleared away" in order to "set the economy free" (1992-01-28). This view that taxes and regulations constitute impediments to freedom has been central to the Republican platform since Reagan. Like his father, George W. Bush also vowed to remove "needless regulations, unnecessary, burdensome, cumbersome, costly regulations" (2001-03-26). He was particularly fond of the expression "tax relief" which he used more than any other president. This metaphorical phrase frames taxes as a form of affliction to be eliminated or from which one wishes to be liberated (Lakoff 2006: 13). The Democratic presidents of the post-Cold War era used this same expression repeatedly.

Regarding deregulation, Bill Clinton continued the policy of the previous administrations, especially after the Democrats lost both the House and the Senate in the 1994 midterm elections. ${ }^{2} \mathrm{He}$ also boasted of "reducing government positions, cutting government programs and eliminating regulations," giving "states the freedom from burdensome Federal Government regulations" (1995-07-08, 1995-07-15). Sixteen years after Ronald Reagan, Bill Clinton tried to close the debate on the role of government by promoting an intermediate vision where "government is not the problem, and government is not the solution." (1997-01-20). His view of government was also defined in relation to freedom: he advocated for "a government that empowers our people to make the most of their own lives but is smaller and less bureaucratic and less burdensome than it has been" (1995-07-15).

Barack Obama also tried to strike a balance between government action and freedom. He advocated rolling back government intervention in "instances where the gains in security from government action are not worth the added constraints on our freedom" (2009-09-09). Early in his presidency, he made clear that he did not believe that government had the answer to every problem, emphasizing that the United States was "a nation built on the strength of individual initiative" (2009-03-14). His attempt at giving a definition that would please both conservatives and progressives is best illustrated in his 2012 State of the Union address when he evoked "Republican Abraham Lincoln" and his belief that "government should do for people only what they cannot do better by themselves and no more" (2012-01-24). In practical terms, this vision of what he called a "smart government" meant a limited role for government within specific areas such as defense, education, transports, research, Medicare and Medicaid, Social Security and unemployment insurance (2012-04-12). At the same time, he pointed out that "the danger of too much government is matched by the perils of too little, that without the leavening hand of wise policy, markets can crash, monopolies can stifle competition, the vulnerable can be exploited" (2009-09-09).

Even the 2007 subprime mortgage crisis, followed by the 2008 financial meltdown and major economic crisis did not alter the dominant narrative. Even as he admitted that he had to "step in with dramatic Government action," George W. Bush continued to 
profess his strong belief in "free enterprise" and assured the public that his "natural instinct [was] to oppose Government intervention" (2008-09-24). ${ }^{3}$ In October 2008, he warned that "the Government's role will be limited and temporary [....] that these measures are not intended to take over the free market, but to preserve it" (2008-14-10). Even in the post-economic crisis era, Barack Obama was very cautious in his rhetoric, pushing back against accusations of hampering freedom through regulations. As he promoted "commonsense safeguards to protect the American people," he also ordered "a review of Government regulations" in order to "reduce barriers to growth and investment" (2011-01-25). Ten months before the 2012 presidential elections, the president was on the defensive:

I've approved fewer regulations in the first three years of my Presidency than my Republican predecessor did in his. I've ordered every federal agency to eliminate rules that don't make sense. (State of the Union, January 24, 2012) encouraged "fair competition" (2015-01-20). Despite the clear differences between Republicans and Democrats on the role of government, the dominant narrative of American politics is still the relationship between government involvement and personal freedom.

President Trump has offered the most negative rhetoric on government. ${ }^{4}$ In terms of domestic economic policy, he has eliminated more regulations and cut more taxes than his predecessors, at least in terms of raw numbers. ${ }^{5}$ From a traditional conservative viewpoint, he conceives of regulations in terms of interference to freedom; they "tie down" the economy and "chain up" prosperity (2017-06-09). Taxes and regulations are framed as "crushing," "crippling" and even "punishing." Trump wants to "free our economy [...] from the terrible tax burdens," particularly, he insists, the "workers that are so burdened with taxes" (2017-11-09, 2017-11-29). Similarly, the Paris Climate Accord "hamstrings the US" and keeps it "tied up" and "bound down" (2017-06-01). As a showman, President Trump even acted out the red-tape metaphor by literally cutting a red ribbon symbolizing 'Red Tape' while standing next to several huge stacks of paper during his address on deregulation (Brenna 2018). In his remarks, he clearly opposed regulations with freedom, and with the "national spirit" of a people, made of "explorers and pioneers and innovators and inventors," who have been hurt badly by regulations. He concluded by saying: "let's cut the red tape. Let's set free our dreams" (2017-12-14).

\section{Health Care and the Market Narrative}

Even in the context of the dominant narrative that opposes government intervention with freedom, there remain ideological differences between Republicans and Democrats. It is probably the subject of health care that best illustrates this framing war for the meaning of freedom. In his 1985 State of the Union Address, Ronald Reagan considered health-care vouchers as a way to "help working families shop for services that they need" (1985-02-06). Here, the verb "shop" implies that health care is a consumer service like any other, and that people should be able to choose a particular service. In the following decades, the question of health care would become the focal point that illustrates the divide between the two parties. Tellingly, in 1992, at a campaign fundraiser, George $\mathrm{H}$. Bush called heath care "the Grand Canyon of philosophy that separates the two sides in this election" (1992-08-02). He warned 
against a move toward "a nationalized system, a system which will restrict patient choice" (1992-01-28). His son, George W. Bush, also raised the specter of "a nationalized health-care system" that would "dictate coverage and ration care" (2003-01-28). Donald Trump has adopted a very similar rhetoric about health care. He speaks of "empowering States and consumers," so they have "the choice and the freedom to make the decisions" (2017-03-10). Freedom is thereby associated with choice and opportunity. Interestingly, President Trump mentions the benefit of the market exclusively when he addresses the issue of health care. In his first address before a Joint Session of the Congress in February 2017, he promised to give Americans "the freedom to purchase health insurance across State lines, which will create a truly competitive national marketplace" (2017-02-28). In this respect, he shares the traditional conservative philosophy of his Republican predecessors - the belief in "the power of the private marketplace to let insurers come in and compete for your business," and against "regulations [that] drive up health-care costs" (2017-03-13, 2018-01-29).

Having campaigned on the promise of health-care reform, President Bill clinton first focused on freedom of access to health care for every American family as his primary goal (1995-01-24, 1996-01-23, 2000-01-27). One of the most contentious terms in the health care debate was, and still is, the idea of a "mandate," a requirement that all individuals purchase health insurance constituting an "obvious" restriction of freedom. President Clinton tried to change the narrative by contrasting what some call an "employer mandate" with "the principles of fairness and responsibility", and by turning the fear of cost into the benefit of a "vital investment" and a defense of "freedom of Americans to live without fear" (1993-09-22). Faithful to his centrist approach between traditional liberalism and the conservative alternative, Bill Clinton promised a combination of private market forces and a sound public policy that would support competition with caps on prices if competition did not work (1993-09-22). He framed health care both as a right (2009-09-08) and as a consumer product, urging "Congress to reach across the aisle and write into law a consumer bill of rights" (1998-01-27). As early as in January 1993, in his Remarks and Exchange With Reporters on Health Care Reform, the president chose to talk about "consumer choice" and not, for instance about "patient choice" (1993-01-25).

Like Bill Clinton, Barack Obama framed his reform of health care both in terms of freedom of access for those "who've been denied coverage" and the freedom "to choose an affordable health care plan in a competitive market" (2010-01-27). He also presented himself as the heir of past Republican presidents such as Theodore Roosevelt "who first called for reform" (2009-02-24, 2009-09-09). He referred to Abraham Lincoln's definition of government to illustrate his own vision of a health-care law that relied on a "reformed private market, not on a Government program" (2012-01-24). In his Address Before a Joint Session of the Congress on Health Care Reform in 2009, he also vowed to protect Medicare, a very popular federal program, calling it "a sacred trust that must be passed down from one generation to the next" (2009-09-09). Essentially, the "Patient Protection and Affordable Care Act" retained the previous structure of Medicare, Medicaid, and the market-based insurance through employers. What is striking, however, is that the dominant narrative remains that of the free market. George Lakoff and Elizabeth Wehling observe that the very word "affordable" in the title of the law fits the metaphor of health care as a product, as do other words commonly used by Obama such as "market," "purchase," and "choice" (2012: 21). 
President Obama is very clear: his plan would "give small businesses and uninsured Americans a chance to choose an affordable health care plan in a competitive market" (2010-01-27). As Lakoff and Wheling noted, Barack Obama formulated his health care act by "placing the product metaphor in the context of the commerce clause of the Constitution, Article I, Section 8, which gives Congress the right to regulate commerce" (2012: 21). This is exactly how he presented his reform:

So the fact is, the product of the Affordable Care Act for people without health insurance is quality health insurance that's affordable. And that product is working. It's really good. And it turns out, there's a massive demand for it.

So let me just recap here. The product is good. The health insurance that's being provided is good. It's high quality, and it's affordable. People can save money, significant money, by getting insurance that's being provided through these marketplaces. The prices are lower than we expected, the choice is greater than we expected. (Remarks on the Patient Protection and Affordable Care Act, October 21, 2013)

50 The central question of how the purchase of a "product" can be justifiably imposed by law remains central here. It seems that by framing health care as a consumer product rather than a patient's right, President Obama precisely undermined the very justification for the individual mandate at the heart of his reform. The dissonance between the president's rhetoric and the law may have contributed to the unpopularity of the individual mandate (Karpman and Long 2017). It made it easier for the Trump administration and the GOP to repeal this aspect of the law.

\section{Conclusion}

51 The metaphors employed in presidential discourse from Ronald Reagan to Barack Obama reveal the continuous narrative of a deterministic economic and political model around the idea of economic freedom. Notwithstanding some political differences, at the core is the belief that free markets and free trade are both natural and moral agents that will lead to peace and prosperity for all, if properly applied, and that government intervention should be limited as it represents a restriction of these freedoms. The fallout of the 2008 financial crisis, followed by a government bailout of the system, did not alter this enduring vision in the following years - the economic crisis was seen as a simple malfunction of an otherwise principled system. Even the very contentious topic of health care has been debated through a rhetoric dominated by a strong faith both in the market and in a limited role of government, including by those like clinton and Obama who pushed for strong reforms. This period of about 35 years, from Ronald Reagan to Barack Obama, is thus remarkable for its rhetorical consistency regarding free trade and the free market, but it may be coming to an end.

On the face of it, Donald Trump seems to represent the burlesque embodiment of the neoliberal doctrine: his public persona was shaped by a culture that praises individual survival and competition; he was elected on the promise to run the country like a business; and he has used his presidential power to change the country, deciding and firing at will, while others execute his policy decisions. That is how he has been running his cabinet. His economic rhetoric and policy, however, also constitute a disruption of the narrative that prevailed in the previous 35 years. His rejection of freetrade deals and his lack of interest in free markets and democratic expansion represent a shift away from the neoliberal order towards one of nationalism and protectionism. 
That is why prominent members of the Republican Party have been, for once, vocal in their criticism of Trump's threat of waging a trade war (Aleem 2018). Of course, he is not the first president to take protectionist measures to help entire categories of American industry. Ronald Reagan, while an apologist of free trade and free markets, imposed quotas on Japanese cars in 1981, on steel from Japan and Europe in 1983, and tariffs on Japanese semiconductor products in 1987. But these were limited measures. In the meantime, Reagan negotiated a trade agreement with Canada that led to the 1988 Canada-United States Free Trade Agreement and, ultimately, to NAFTA. More importantly, as political scientist Delia Conti concluded, rhetorically, Ronald Reagan "consistently upheld the ideal of free trade as the theme and goal of his administration" (Conti 1995: 103-4). He was also quite aware of the failed policies of President Herbert Hoover's protectionist measures in the 1930s. One can contrast how Reagan viewed trade wars to what Donald Trump wrote on Twitter:

In the 1930's, the world experienced an ugly specter-protectionism and trade wars and, eventually, real wars and unprecedented suffering and loss of life. (Radio Address to the Nation on International Free Trade November 20,1982)

Trade wars are good and easy to win. [...] we win big. It's easy! (Donald Trump Tweet, @realdonaldtrump, Mar 2, 2018 05:50:34 AM)

Donald Trump's policies may be difficult to assess as his discourse and action often lack consistency, and it may be too early to draw definite conclusions about the long-term influence of his rhetoric on US politics. One issue where he has had a long-standing consistent view is trade: he has often repeated how the US "was not respected," and was "taken advantage of" by the rest of the world, including by its neighbors thanks to NAFTA. As much as Reagan complained about the trade deficit, he was not, like President Trump, ready to take the world to the brink of a trade war as a negotiating tool.

Trump's obsession with the national trade deficit is one of the identifying characteristics of the mercantilist doctrine that held sway in Europe between the $16^{\text {th }}$ and $18^{\text {th }}$ centuries. Its goal was to achieve a favorable trade balance in order to increase or maintain national power and wealth (Magnusson 2015: 6, 21). In those days, wealth was measured by the amount of "international reserves" at the disposal of the state, so international trade was necessarily a zero-sum game where one nation only could win what the other lost. This has been the core of Donald Trump's nationalist discourse about a world made of winners and losers, where every nation has to compete for its share of the cake. That is why, in his inaugural address, he pledged that America would "start winning again, winning like never before" (01-20-2017). Mercantilists wanted to limit competition, and despite his claim that he wants a "fair deal," Trump is not really interested in fair competition: when the European Union offered to scrap tariffs on cars, he said that it was "not good enough" because "the [European] consumer habits are to buy their cars, not to buy our cars" (Micklethwait, Talev, and Jacobs 2018) hardly a statement from someone who believes in either the free market or fair trade deals.

Another characteristic of mercantilist policies was that they were designed to benefit a particular class of society: the merchants and manufacturers (Magnusson 2015: 4). This is also consistent with what seems to be Trump's neoliberal policy: his tax cuts on the wealthy, his deregulation of big business and the financial industry. Despite his constant attack on the so-called "Deep State" (2017-06-16), 2017-11-28), including Federal employees whom he calls "unelected bureaucrats" (2017-02-17c, 2017-07-03, 
2018-01-26), President Trump has not been shy about using the federal powers of his administration to help the coal and oil industries, to put pressure on private companies like Amazon, Boeing and Lockheed (Mufson and Lynch 2018). And, of course, Trump's nationalistic rhetoric, encapsulated by his "America First" slogan and his insistence on national sovereignty and the end of "globalism" is consistent with the mercantilist outlook. His is a new brand of mercantilism based on "a zero-sum conception of the benefits to individual states from international trade" (Ahmed and Bick 2017). "America First" exalts loyalty and devotion to the nation and places the American nation above all others and, even more so, above supranational institutions

One may wonder if Donald Trump may represent a temporary local anomaly or a more long-term global trend signifying the end of a cycle. As nations feel that they have lost power as a result of globalism and the interdependence of free trade, they might want to regain their power by advancing similar policies. The rise of nationalism throughout the world may give us pause. If neoliberalism has failed, its replacement by neomercantilism may be even more worrisome since, as history has taught us, mercantilism and trade wars ultimately leads to real wars between nations. In the light of today's situation, Ronald Reagan's words when he addressed the nation on free trade seem like a cautionary tale:

Yet today protectionism is being used by some American politicians as a cheap form of nationalism [...] Our peaceful trading partners are not our enemies; they are our allies. We should beware of the demagogues who are ready to declare a trade war against our friends - weakening our economy, our national security, and the entire free world - all while cynically waving the American flag. The expansion of the international economy is not a foreign invasion; it is an American triumph, one we worked hard to achieve, and something central to our vision of a peaceful and prosperous world of freedom. (Radio Address to the Nation on the Canadian Elections and Free Trade, November 26, 1988)

\section{BIBLIOGRAPHY}

Ahmed, Salman and Alexander Bick. “Trump's National Security Strategy: A New Brand of Mercantilism?" Carnegie Endowment for International Peace, August 17, 2017. http:// carnegieendowment.org/2017/08/17/trump-s-national-security-strategy-new-brand-ofmercantilism-pub-72816

Aleem, Zeeshan. "Big business and the GOP are declaring war on Trump's trade agenda." Vox, July 3, 2018. https://www.vox.com/world/2018/7/3/17530516/chamber-commerce-trump-tariffstrade-war-china

Alpers, Ben. “The Strange Transatlantic Career of 'Neoliberalism." Society for U.S. Intellectual History (S-USIH), Jan. 4, 2011. https://s-usih.org/2011/01/strange-transatlantic-career-of/ Boas Taylor C. and Jordan Gans-Morse. "Neoliberalism: From New Liberal Philosophy to AntiLiberal Slogan." Studies in Comparative International Development 44 (2) June 2009: 137-61 
Charteris-Black, Jonathan. Corpus Approaches to Critical Metaphor Analysis. London: Palgrave Macmillan, 2004.

Charteris-Black, Jonathan. Politicians and Rhetoric: the Persuasive Power of Metaphor. London: Palgrave Macmillan, 2011.

Chilton, Paul. Analyzing Political Discourse. London: Routledge, 2004.

Coles, T.J. President Trump, Inc. - How Big business and Neoliberalism Empower Populism and the farRight. West Hoathly: Clairview Books, 2017.

Conti, Delia B. “President Reagan's Trade Rhetoric: Lessons for the 1990s.” Presidential Studies Quarterly 25 (1) Winter 1995: 91-108.

Davies, William. The Limits of Neoliberalism, Authority, sovereignty, and the Logic of competition. London: Sage, 2017.

Donnan, Shawn. “Trump's New Nafta Pact Looks More Like a Rebranding Than a Revolution.” Bloomberg Business Week, Oct. 1 2018. https://www.bloomberg.com/news/articles/2018-10-01/ trump-s-new-nafta-pact-looks-more-rebranding-than-revolution

Eubanks, Philip. A War of Words in the Discourse of Trade: The Rhetorical Constitution of Metaphor. Carbondale: Southern Illinois UP, 2000.

Fuchs, Christian. "Donald Trump: A Critical Theory-Perspective on Authoritarian Capitalism." TripleC: Communication, Capitalism \& Critique. Open Access Journal for a Global Sustainable Information Society 15 (1) 2017: 1-72. DOI: 10.31269/triplec.v15i1.835

Fukuyama, Francis. The End of History and the Last Man. New York: Free Press, 1992.

Godwin, Jack. Clintonomics: How Bill Clinton Reengineered the Reagan Revolution. AMACOM, 2009.

Hamington, Maurice. "Business Is Not a Game: The Metaphoric Fallacy." Journal of Business Ethics. 86 (4) June 2009: 473-84.

Jacobson, Louis. "Donald Trump cites Ronald Reagan as a protectionist hero. Was he?" Politifact, July 1st, 2016. http://www.politifact.com/truth-o-meter/article/2016/jul/01/donald-trumpcites-ronald-reagan-protectionist-her/

Jopson, Barney. "Trump has cut less red tape than his rhetoric suggests." The Financial Times, January 29, 2018. https://www.ft.com/content/3f7df21a-fd68-11e7-a492-2c9be7f3120a

Karpman, Michael, and Sharon K. Long. "Adults Who Would Be Most Affected by ACA Repeal Support Keeping Core ACA Provisions.” Washington, DC: Urban Institute, 2017.

Kessler, Glenn. "Has Trump cut more regulations than any president in history?" The Washington Post, October 12, 2017. https://www.washingtonpost.com/news/fact-checker/wp/2017/10/12/ has-trump-cut-more-regulations-than-any-president-in-history/?utm_term=.16f3f45ag 94 Lakoff, George. "Metaphor and War: The Metaphor System Used to Justify War in the Gulf." Journal of Urban and Cultural Studies 2 (1) 1991: 59-72.

Lakoff, George. Whose Freedom? The Battle Over America's Most Important Idea. New York: Farrar, Straus and Giroux, 2006.

Lakoff, George. Don't Think of an Elephant! Know Your Values and Frame the Debate. Hartford: Chelsea Green, 2014.

Lakoff, George, and Mark Johnson. Metaphors We Live By. Chicago: U. of Chicago P., 1981. 
Lakoff, George and Elisabeth Wheling, The Little Blue Book: The Essential Guide to Thinking and Talking Democratic. New York: Free Press, 2012.

Magnusson, Lars. The Political Economy of Mercantilism. London: Routledge, 2015.

McNaught, Mark Bennett, La religion civile américaine, de Reagan à Obama. Rennes: Presses Universitaires de Rennes, 2009.

Micklethwait John, Margaret Talev, and Jennifer Jacobs. "EU Offer for No Auto Tariffs Is 'Not Good Enough,' Trump Says.” Bloomberg, August 30, 2018. https://www.bloomberg.com/news/ articles/2018-08-30/trump-says-eu-offer-for-no-auto-tariffs-is-not-good-enough

Mirowski, Philip. Never Let a Serious Crisis Go to Waste: How Neoliberalism Survived the Financial Meltdown. London: Verso, 2013.

Monbiot, George."Neoliberalism - the ideology at the root of all our problems." The Guardian, April 15, 2016. https://www.theguardian.com/books/2016/apr/15/neoliberalism-ideologyproblem-george-monbiot

Mufson, Steven and David J. Lynch. "Breaking from GOP orthodoxy, Trump increasingly deciding winners and losers in the economy." The Washington Post, June 1, 2018. https:// www.washingtonpost.com/business/economy/from-electricity-to-steel-trump-becomingincreasingly-active-in-trying-to-shape-the-economy/2018/06/01/c1a0692c-65b3-11e8-a69cb944de66d9e7_story.html?utm_term=.9c8a29dbe583

Nelson, Thomas E., Zoe M. Oxley and Rosalee A. Clawson. "Toward a Psychology of Framing Effects." Political Behavior 19 (3) Sep., 1997: 221-4.

Palley, Thomas I. "From Keynesianism to Neoliberalism: Shifting Paradigms in Economics." In Alfredo Saad-Filho and Deborah Johnston. Neoliberalism: A Critical Reader. London: Pluto Press, 2005. 20-30.

Peck, Jamie. Constructions of Neoliberal Reason. Oxford: Oxford UP, 2010.

Peters, Charles. "A Neoliberal Manifesto, Community, Prosperity, Democracy: A platform for the future.” The Washington Monthly, May 1983, 8-18.

Rasmus, Jack. “Trump Scraps The Trans-Pacific Partnership (TPP) for Bilateral “Free Trade.” Global Research, February 8, 2017.

Scacco, Josh. "Shaping Economic Reality: A Critical Metaphor Analysis of President Barack Obama's Economic Language During His First 100 Days." Gnovis - Georgetown Journal of Communication, Culture \& Technology 10 (1) December 22, 2009. http://www.gnovisjournal.org/ 2009/12/22/shaping-economic-reality-critical-metaphor-analysis-president-barack-obama-seconomic-langua/

Slotkin, Richard. Gunfighter Nation : the Myth of the Frontier in Twentieth Century America. New York: Harper Perennial,1993.

Stedman-Jones, Daniel. "The American Roots of Neoliberalism." History News Network, The George Washington University, March 15, 2013. https://historynewsnetwork.org/article/151023

Steger, Manfred B. and Ravi K. Roy. Neoliberalism: A Very Short Introduction. Oxford: Oxford UP, 2010.

Thurow, Lester C. Dangerous Currents: The State of Economics. New York: Random House Inc, 1984.

Twadzisz, Piotr. The Language of Interstate Relations, In Search of Personification. London: Palgrave Macmillan, 2014. 
Viala-Gaudefroy, Jérôme. "President Trump and the Virtue of Power." Revue LISA/LISA e-journal XVI (2) 2018. DOI : 10.4000/lisa.9861

Williams, Brenna. "Trump literally cuts the red tape on regulations." CNN, December 14, 2017. https://edition.cnn.com/2017/12/14/politics/trump-deregulation-in-gifs/index.html Williamson, John. “A Guide to John Williamson's Writing." Peterson Institute for International Economics, 2015. https://web.archive.org/web/20150705172400/http://www.iie.com/content/? ID=1\#topic3

\section{Corpus}

\section{Ronald Reagan}

1983-11-20, Radio Address to the Nation on International Free Trade November 1983-08-06, Radio Address to the Nation on International Trade

1983-11-20, Radio Address to the Nation on International Free Trade November 1985-02-06, Address Before a Joint Session of Congress on the State of the Union 1984-05-01, Remarks Upon Returning From China 1985-03-28, Remarks to Brokers and Staff of the New York Stock Exchange in New York 1985-05-24, Remarks at the Annual Meeting of the National Association of Manufacturers 1985-06-21, Remarks at the Annual Convention of the Lions Club International in Dallas, Texas 1986-09-22, Address to the $41^{\text {st }}$ Session of the United Nations General Assembly in New York 1987-06-12, Remarks on East-West Relations at the Brandenburg Gate in West Berlin 1987-09-21, Address to the $42^{\text {nd }}$ Session of the United Nations General Assembly in New York 1988-01-25, Address Before a Joint Session of Congress on the State of the Union 1988-05-05, Proclamation of World Trade Week

\section{George H. W. Bush}

1989-02-09, Address on Administration Goals Before a Joint Session of Congress 1989-09-25, Address to the $44^{\text {th }}$ Session of the United Nations General Assembly in New York 1989-11-22, Thanksgiving Address to the Nation 1990-01-12, Remarks to the Chamber of Commerce in Cincinnati, Ohio 1990-01-31, Address Before a Joint Session of the Congress on the State of the Union 1990-02-05, Remarks to the Intergovernmental Panel on Climate Change 1990-03-08, Remarks at the National Transportation Policy Meeting 1990-05-12, Remarks at the Liberty University Commencement Ceremony in Lynchburg, Virginia 1990-12-03, Remarks to a Joint Session of the Congress in Brasilia, Brazil 1991-02-06, Remarks and a Question-and-Answer Session at a Meeting of the Economic Club in New York

1991-09-23, Address to the $46^{\text {th }}$ Session of the United Nations General Assembly in New York City 
1992-01-28, Address Before a Joint Session of the Congress on the State of the Union 1992-03-06, Remarks at Louisiana State University in Baton Rouge, Louisiana 1992-08-02, Remarks at a Fundraising Brunch for Rich Williamson in Rosemont, Illinois

\section{Bill Clinton}

1993-01-25, Remarks and an Exchange With Reporters on Health Care Reform 1993-02-17, Address Before a Joint Session of Congress on Administration Goals 1993-02-26, Remarks at the American University Centennial Celebration.

1993-03-26, The President's News Conference With Chancellor Helmut Kohl of Germany 1993-04-01, Remarks to the American Society of Newspaper Editors in Annapolis 1993-07-26, Remarks to the Conference on the Future of the American Workplace in Chicago, Illinois

1993-09-22, Address to a Joint Session of the Congress on Health Care Reform

1993-09-27, Remarks to the $48^{\text {th }}$ Session of the United Nations General Assembly in New York

1993-11-20, The President's Radio Address

1993-12-15, The President's News Conference

1994-07-07, Address to the Polish Parliament in Warsaw

1994-09-28, Partnership for Economic Progress: Joint Statement on Principles and Objectives for the Development of Trade, Economic Cooperation, and Investment

1997-10-24, National Consumers Week

1995-01-24, Address Before a Joint Session of the Congress on the State of the Union 1995-07-08, The President's Radio Address

1995-07-15, The President's Radio Address July

1996-01-23, Address Before a Joint Session of the Congress on the State of the Union 1996-08-05, Remarks on International Security Issues at George Washington University 1997-01-20, Inaugural Address

1997-02-04, Address Before a Joint Session of the Congress on the State of the Union 1997-02-24, Statement Announcing the Fast Track Legislation Team

1997-09-22, Remarks to the $52^{\text {nd }}$ Session of the United Nations General Assembly in New York 1997-11-08, The President's Radio Address

1998-05-18, Remarks at the World Trade Organization in Geneva, Switzerland 1998-01-27, Address Before a Joint Session of the Congress on the State of the Union 1999-06-12, Commencement Address at the University of Chicago in Chicago, Illinois 2000-01-27, Address Before a Joint Session of the Congress on the State of the Union 


\section{George W. Bush}

2001-06-15, Address at Warsaw University

2001-07-01, Remarks at the World Bank

2001-03-26, Remarks to the Community in Billings

2002-01-29, Address Before a Joint Session of the Congress on the State of the Union

2002-05-14, Remarks on Signing the Enhanced Border Security and Visa Entry Reform Act of 2002

2002-09-26, Remarks at the Corporate Fraud Conference

2003-01-28, Address Before a Joint Session of the Congress on the State of the Union

2003-05-09, Commencement Address at the University of South Carolina in Columbia, South

Carolina

2003-05-21, Commencement Address at the United States Coast Guard Academy in New London, Connecticut

2003-11-11, Remarks at the Heritage Foundation President's Club Luncheon

2004-01-20, Address Before a Joint Session of the Congress on the State of the Union

2005-09-14, Remarks to the Plenary Session of the United Nations General Assembly in New York City

2005-02-21, Remarks in Brussels, Belgium,

2006-01-31, Address Before a Joint Session of the Congress on the State of the Union

2006-02-15, Remarks on Health Care in Dublin, Ohio

2006-07-21, Remarks at the Port of Miami in Miami

2006-10-13, Remarks on Signing the Security and Accountability For Every Port Act of 2006

2008-01-28, Address Before a Joint Session of the Congress on the State of the Union

2008-04-21, Remarks at a United States Chamber of Commerce Reception in New Orleans

2008-09-24, Address to the Nation on the National Economy

2008-10-10, Remarks on the National Economy

2008-11-13, Remarks to the Manhattan Institute in New York City

2008-11-14a, The President's Radio Address

2008-11-14b, Remarks at a State Dinner With Financial Markets and World Economy Summit Participants

2008-11-15, Remarks at the Summit on Financial Markets and the World Economy

\section{Barack Obama}

2009-01-20, Inaugural Address

2009-02-10, Remarks on Economic Stabilization and a Question-and-Answer Session in Fort

Myers, Florida

2009-02-24, Address Before a Joint Session of the Congress

2009-03-14, The President's Weekly Address 
2009-04-03, Remarks at a Town Hall Meeting and a Question-and-Answer Session in Strasbourg 2009-04-14, Remarks on the National Economy, 2009-05-17, Commencement Address at the University of Notre Dame in South Bend, Indiana 2009-09-09, Address Before a Joint Session of the Congress on Health Care Reform 2010-01-27, Address Before a Joint Session of the Congress on the State of the Union 2010-08-09, Remarks at the University of Texas at Austin in Austin 2011-01-25, Address Before a Joint Session of the Congress on the State of the Union 2011-01-28, Remarks at the Families USA Health Action 2011 Conference, 2011-03-19, Remarks to the Brazil-United States Business Council Summit in Brasilia 2011-03-28, Address to the Nation on the Situation in Libya 2011-05-25, Remarks to the Parliament in London 2011-09-11, Remarks at "A Concert for Hope" Commemorating the $10^{\text {th }}$ Anniversary of the September 11 Terrorist Attacks

2011-11-17, Remarks to the Parliament in Canberra,

2012-01-24, Address Before a Joint Session of the Congress on the State of the Union 2012-04-10, Remarks at Florida Atlantic University in Boca Raton, Florida 2012-05-19, Camp David Declaration 2013-02-12, Address Before a Joint Session of Congress on the State of the Union, 2013-10-21, Remarks on the Patient Protection and Affordable Care Act, 2014-11-07, Statement on the $25^{\text {th }}$ Anniversary of the Fall of the Berlin Wall 2015-01-20, Address Before a Joint Session of the Congress on the State of the Union

\section{Donald Trump}

2017-01-25, Remarks at the Department of Homeland Security

2017-02-17, Remarks at the Boeing Company Manufacturing Facility in North Charleston, South Carolina

2017-02-24, Remarks at the Conservative Political Action Conference in National Harbor, Maryland

2017-02-27, Remarks to the National Governors Association

2017-02-28, Address Before a Joint Session of the Congress

2017-02-28, Address Before a Joint Session of the Congress

2017-03-10, The President's Weekly Address

2017-05-18, The President's News Conference With President Juan Manuel Santos Calderon of Colombia

2017-06-01, Remarks Announcing United States Withdrawal From the United Nations Framework Convention on Climate Change Paris Agreement

2017-06-09, Remarks by President Trump on Regulatory Relief 
2017-29-04, Remarks at a "Make America Great Again" Rally in Harrisburg, Pennsylvania

2017-10-11, Remarks at the Asia-Pacific Economic Cooperation CEO Summit in Danang, Vietnam

2017-11-29, Donald Trump on Tax Reform in St. Charles, Missouri

2017-12-14, Remarks on Deregulation

2018-01-29, Remarks at a Swearing-In Ceremony for Secretary of Health and Human Services Alex M. Azar II and an Exchange With Reporters

2018-02-02, Exchange With Reporters at the United States Customs and Border Protection's National Targeting Center in Sterling, Virginia.

2018-02-23, Remarks at the Conservative Political Action Conference in Oxon Hill, Maryland.

2018-03-02, @realdonaldtrump, 05:50:34 AM.

\section{NOTES}

1. The expression "economic machine" itself can be traced back to President Herbert Hoover who used it in the years following the crash of 1929, for instance when he expressed his hope that his economic recovery program will "further process of speeding up the economic machine" in his Statement About Unity of Action on the Economic Recovery Program (May 13, 1932). Source: The American Presidency Project, http://www.presidency.ucsb.edu/ws/index.php? pid=23085\&st=economic + machine\&st 1

2. See for instance Clinton's 1996 Telecommunications Act PL 104-104, or his 1999 Gramm-LeachBliley Act PL 106-102 in the financial sector, which ultimately led to the 2008 meltdown. See also Jack Godwin (2009).

3. The Emergency Economic Stabilization Act of 2008 is commonly referred to as a bailout of the US financial system.

4. Besides his negative rhetoric on the government's role in the economy, President Trump has also launched a most aggressive campaign against his own government agencies such as the CIA, the FBI and the Department of Justice, and has greatly undermined the Environmental Protection Agency. This attack on the administrative state is at the core of the alt-right ideology represented by the president's senior advisor for policy Steve Miller or former White House Chief Strategist Stephen Bannon (Viala-Gaudefroy 2018).

5. It is still early regarding the assessment of Trump's deregulation. See Kessler (2017) and Jopson (2018).

\section{ABSTRACTS}

Neoliberalism is a complex and ambiguous concept that has been consistently referred to by critics of an economic policy based, at least rhetorically, on free market and free trade in the last few decades. These two major tenets of neoliberalism have dominated the discourse of American presidents since the beginning of the 1980s. The same period has also been characterized by an increased tendency to tie these economic policies to freedom, a core value of American identity 
that came to be defined primarily in economic terms. Starting with Ronald Reagan, economic freedom rather than political liberty became the measure of virtue, as the "free world" admitted more authoritarian regimes in its ranks in the name of anti-communism (Numberg 2003). The collapse of the Soviet bloc only served to bolster the vision that free market and free trade alone could bring prosperity and political freedom. This would become the dominant worldview at international institutions such as the World Bank and the IMF and would be solidified in the rhetoric of Republican and Democratic presidents alike (McNaught 2009). Drawing on the rhetorical and cognitive approaches developed by Lakoff and Johnson (1981), Chilton (2004) and Charteris-Black (2011), this paper analyses how conceptual metaphors in presidential discourse have contributed to creating a mythical vision of free trade and free market since the 1980s. The metaphors of movement, journey, nature, machine and sport resonate with the way Americans understand and experience their national identity, at the center of which are the values of freedom, competition and progress. They have turned an abstract economic philosophy into a comprehensible and sacred story at the heart of the American model. This model has been one of expansion of free markets and free trade. It has also been pervasive even in the domestic sphere, in the way a divisive issue like health care was framed through a positive market narrative. Despite policies that may have occasionally seemed to contradict the faith in the market, especially in the wake of the 2008 financial and economic meltdown, presidential discourse remained focused on free trade and free markets. This economic crisis may have triggered the first cracks in the mostly consensual view of free trade and free market in political rhetoric across the board. This article argues that much as there was a neoliberal consensus for 35 years, President Trump has been the great disrupter of neoliberal rhetoric by rejecting free trade agreements and by ignoring altogether the virtue of free market, a notion almost entirely absent from his discourse. He has replaced the neoliberal doxa with a discourse centered on the trade deficit and on short-term accumulation of national wealth and power. He has embraced the virtue of national sovereignty while rejecting what he called "globalism". He has offered an antagonistic vision of a world in which international trade is conceived as a zero-sum game. This new vision is reflected in the metaphors used by a president who has challenged the norms of presidential rhetoric at many levels.

Le néolibéralisme est un concept complexe et ambigu, auquel se sont constamment référés, au cours des dernières décennies, les critiques d'une politique économique promouvant, sur le plan rhétorique au moins, le marché et le libre-échange. Ces deux principes majeurs du néolibéralisme ont dominé le discours des présidents américains depuis les années 80 . Cette même période a vu une tendance croissante à associer les politiques économiques à la liberté, une valeur au cœur de l'identité américaine qui a été finalement définie en termes économiques. C'est notamment avec Ronald Reagan que la liberté économique plutôt que la liberté politique est devenue systématiquement la mesure de la vertu. Ceci alors que le «monde libre » acceptait des régimes autoritaires dans ses rangs au nom de l'anticommunisme (Numberg 2003). L'effondrement du bloc soviétique n'a fait que renforcer l'idée que, seuls, le marché et le libre échange pouvaient conduire à la prospérité et à la liberté politique. Ce qui deviendra le point de vue dominant d'institutions internationales comme la Banque mondiale ou le FMI et allait davantage s'ancrer dans la rhétorique des présidents aussi bien républicains que démocrates (McNaught 2009). Cet article s'appuie sur l'approche cognitive développée par Lakoff et Johnson (1981), Chilton (2004) ainsi que Charteris-Black (2011). Il propose d'analyser comment, dans les discours présidentiels, les métaphores conceptuelles ont contribué à la création d'une vision mythifiée du libre-échange et du marché construite depuis le début des années 80. Ces métaphores du mouvement, du voyage, de la nature, de la machine et du sport font écho à la façon dont les Américains conçoivent et expérimentent leur identité nationale fondée sur les valeurs de liberté, de compétition et de progrès. Elles ont permis de transformer une philosophie économique abstraite 
en un récit compréhensible et sacré au cœur du modèle américain. Ce modèle d'expansion du marché et du libre-échange est omniprésent. Il a également envahi la politique intérieure, comme le montre l'analyse rhétorique des prises de position sur un sujet controversé comme la santé, formulées à l'aide d'un récit positif sur le marché. Alors que les effets suscités par les politiques menées ont occasionnellement semblé contredire la foi dans le marché, particulièrement à la suite de la crise économique et financière de 2008, la rhétorique présidentielle est restée la même. Or il s'avère que cette crise $a$, in fine, pu être un des déclencheurs des premières fissures dans la vision consensuelle du marché et du libre-échange dominant la politique américaine. Cet article démontre que le président Trump a largement perturbé le consensus rhétorique néolibéral en rejetant les accords de libre-échange et en ignorant complètement les vertus d'un marché complètement absent de son discours. Il a ainsi remplacé la doxa néolibérale par une rhétorique centrée sur le déficit commercial et l'accumulation à court terme de richesse et de puissance nationale. Il a fait de la souveraineté nationale la vertu cardinale et rejeté ce qu'il qualifie de "mondialisme». Il offre une vision antagoniste d'un monde dans lequel le commerce international est conçu comme un jeu à somme nulle. Cette nouvelle vision se reflète dans les métaphores utilisées par un président qui a remis en cause la rhétorique présidentielle à plus d'un titre.

\section{INDEX}

Mots-clés: néolibéralisme, États-Unis, marché, libre échange, métaphores conceptuelles, rhétorique, discours présidentiels, État, mercantilisme

Keywords: neoliberalism, United States, free market, free trade, conceptual metaphors, presidential rhetoric, discourse, government, mercantilism

\section{AUTHOR}

\section{JÉRÔME VIALA-GAUDEFROY}

Part-time lecturer at Université Paris 3 - Sorbonne Nouvelle. Jérôme Viala-Gaudefroy recently published an article on "President Trump and the Virtue of Power" in the e-journal LISA, vol. $\mathrm{XVI}-\mathrm{n}^{\circ} 2$ (2018). He is also a contributor to the independent, not-for-profit online publication, The conversation. He has been the webmaster the AFEA (Association française d'études americaines) and an active member of the board since 2013. Contact: jerome.viala[at]sorbonne-nouvelle.fr 